\title{
Weeding method and pre-sowing tillage effects on weed growth and pearl millet yield in a sandy soil of the West African Sahelian zone
}

\author{
M.C. Klaij ${ }^{\text {a, }}$, W.B. Hoogmoed ${ }^{b}$ \\ a ICRISAT Sahelian Center, B.P. 12404, Niamey, Niger \\ ${ }^{b}$ Tillage Lahoratory. Agricultural University, Diedenweg 20.6703 GW Wageningen. Netherlands
}

Accepted 23 May 1996

\begin{abstract}
Weed control for the West African Sahel rainfed crops is done mainly manually, resulting in high labor requirements. Because of the seasonality of rainfed farming, weed control is often late and incomplete, resulting in considerable losses in crop yield. We examined the case of weed control in continuously cultivated pearl millet (Pennisetum glaucum (l.) R. Br.) on a sandy soil. During 3 years we evaluated the effects of pre-sowing ridging and combinations of hand and mechanical weeding powered by donkeys on: seasonal weed growth (separating within-row and between-row weeds), pearl millet yield, and labor requirements for weeding. Four weeding methods resulted in levels of weed control decreasing in the order: full fjeld hand weeding $\left(W_{f}\right)$; between-row weeding by animal traction plus additional within-row hand weeding $\left(W_{a+h}\right)$; between-row weeding by animal traction $\left(\mathrm{W}_{\mathrm{a}}\right)$; and no weeding $\left(\mathrm{W}_{0}\right)$. Weeding method was the single most important factor that affected weed growth and, hence crop yields. Depending on the year, average weed dry matter at harvest ranged from 140 to $270 \mathrm{~kg} \mathrm{ha}^{-1}$ for method $W_{\mathrm{f}}$ to 3000 to $3520 \mathrm{~kg} \mathrm{ha}^{-1}$ for method $\mathrm{W}_{0}$. Correspondingly, the highest millet yields ranging from 279 to $1012 \mathrm{~kg} \mathrm{ha}^{-1}$ were obtained with $W_{\mathrm{f}}$ with a total weeding labor requirement of $70.1 \mathrm{~h} \mathrm{ha}^{-1}$. The $\mathrm{W}_{\mathrm{a}+\mathrm{h}}$ method required $51.8 \mathrm{~h} \mathrm{ha}^{-1}$ and resulted in yields, depending on the year, that were 78 to $100 \%$ of the $W_{f}$ method. The $W_{a}$ method resulted in unchecked within-row weed growth that exceeded those in weedy check plots, and reduced crop yield to 28 to $34 \%$ of $\mathrm{W}_{\mathrm{f}}$. Finally, unchecked weeds reduced yield to 2 to $10 \%$ of $\mathrm{W}_{\mathrm{f}}$.
\end{abstract}

Pre-sowing tillage reduced seasonal weed growth, increased crop yields, and was particularly

* Corresponding author at: ILRI, P.O. Box 5689, Addis Ababa, Ethiopia. 
effective in reducing the amount of crop weeds for the $\mathrm{W}_{\mathrm{a}}$ weed control method. The continuous growing of millet did not change the amount of seasonal weed dry matter during the experiment.

Keywords: Tillage; Mechanical and manual weed control; Pearl millet yield losses; Within-row and betweenrow weed growth; Alfisol; Semi-arid tropics

\section{Introduction}

The seasonality of rainfed field crop cultivation imposes a serious bottleneck in terms of time and amount of weeding, particularly where weeding is commonly dependent on manual labor (Norman et al., 1981). As many as $256 \mathrm{~h} \mathrm{ha}^{-1}$ in Senegal and $129 \mathrm{~h} \mathrm{ha}^{-1}$ in Mali are reported to be required for weeding for the cultivation of pearl millet and sorghum (Sorghum bicolor (L.) Moench) (Norman et al., 1981). Somewhat lower work rates are estimated for the millet-based subsistence cropping systems typical of the sandy soils of Niger. In a replicated large plot experiment, hand weeding required $148 \mathrm{~h}$ $\mathrm{ha}^{-1}$ in 1986 and $95 \mathrm{~h} \mathrm{ha}^{-1}$ in 1987 (International Crops Research Institute for the Semi-Arid Tropics, ICRISAT, 1988). Late and incomplete weeding is common in the Sahel and results in potential crop yield losses.

Crop yield losses caused by uncontrolled weeds are as high as $70 \%$ in India for millet and sorghum (ICRISAT, 1976), and ranged from 10 to $90 \%$ in experiments on mechanical weed control for millet and sorghum (Klaij, 1983). In the savannah area of Northern Nigeria grain losses were $71 \%$ for millet (Choudhary and Lagoke, 1981). Millet grain losses associated with farmers weeding practices ranged from 27 to $36 \%$ for early millet in the Gambia (Carson, 1987). These losses were attributed to poor land preparation and lack of within-row weeding. Indeed, primary tillage plays an important role in year round weed management (Kuipers, 1975).

In the West African Sahelian zone fallow periods have been shortened and millet is increasingly grown continually, which has implications both for crop yield and weed management. Considerable research has been invested in developing more intensive cultivation methods for millet using low levels of external inputs. Pre-sowing ridging using animal traction, application of modest doses of phosphorus fertilizer, and use of increased plant densities have increased millet yields substantially (Klaij et al., 1994). Between-row weeding with donkey drawn weeders reduced farmers' weeding effort by $50 \%$ (ICRISAT, 1991). However, little research has been reported in the region on weeding time requirements, the effects of pre-sowing tillage and weeding on weed growth, and the potential losses of a millet crop. Therefore, we conducted a 3-year study to evaluate the effectiveness of pre-sowing tillage, combinations of hand weeding and animal-powered between-row weeding, and millet cultivar on seasonal weed growth and crop yield components.

\section{Materials and methods}

\subsection{Experimental site}

The study was conducted from 1987 to 1989, at the ICRISAT Sahelian Center $\left(13^{\circ} 48^{\prime} \mathrm{N} ; 5^{\circ} 15^{\prime} \mathrm{E}\right.$, altitude $\left.272 \mathrm{~m}\right), 45 \mathrm{~km}$ south of Niamey, Niger. Soil and climate 
parameters have been described in detail by Hoogmoed and Klaij (1990). The soil is sandy with total sand (particle size 0.02 to $2.0 \mathrm{~mm}$ ) decreasing from $920 \mathrm{~g} \mathrm{~kg}^{-1}$ at the surface to $890 \mathrm{~g} \mathrm{~kg}^{-1}$ at $1.5 \mathrm{~m}$-depth, while clay (particle size $<2 \mu \mathrm{m}$ ) content increased from $40 \mathrm{~g} \mathrm{~kg}^{-1}$ to $80 \mathrm{~g} \mathrm{~kg}^{-1}$. When wet, the topsoil is very friable, non-sticky, and non-plastic, attributes that greatly facilitate tillage and weeding. The soil is a sandy Psammentic Paleustalf: sandy, silicious isohyperthermic according to the USDA classification system (West et al., 1984). It is classified an Arenosol on the FAO/UNESCO soils map of 1977 (FAO/UNESCO, 1977). This soil is the major soil unit in the 60 to 100 days length of growing season band comprising the Southern Sahelian zone (ICRISAT, 1992). At the start of the experiment the soil had not been cultivated for 5 years. Soil organic matter content of the top $0.2-\mathrm{m}$ layer was $4.2 \mathrm{~g} \mathrm{~kg}^{-1}$ soil $(\mathrm{SE}=0.18)$ and $\mathrm{P}-\mathrm{Bray}_{1}$ was $6.2 \mu \mathrm{g} \mathrm{g}^{-1}$ soil $(\mathrm{SE}=1.90)$. Mean annual rainfall in Niamey is $560 \mathrm{~mm}$ (1961-1990 rainfall data) with most of the rain received between June and September.

\subsection{Experimental treatments}

We evaluated the factors tillage, weeding and pearl millet cultivar. Annual pre-sowing ridging was compared with the traditional system that involves no primary tillage, further referred to as no-till. Ridges were made without prior tillage using a John Deere 984 integral four-row bedder with staggered disks set to a ridge spacing of $0.75 \mathrm{~m}$ and ridge height of $0.20 \mathrm{~m}$. Ridging was executed yearly, after the first rain in May or June that exceeded $8 \mathrm{~mm}$. The weeding methods compared were aimed at increasing level of control: between-row cultivation only $\left(\mathrm{W}_{\mathrm{a}}\right)$, between-row cultivation supplemented with in-row hand weeding $\left(\mathrm{W}_{\mathrm{a}+\mathrm{h}}\right)$, and full field hand weeding $\left(\mathrm{W}_{\mathrm{f}}\right)$. A fourth treatment in which weeds were allowed to grow was included $\left(W_{0}\right)$. Weeding was done twice each crop cycle. The between-row weeding for method $\mathrm{W}_{\mathrm{a}}$ was done in a single pass using a donkey pulling an expandable weeder weighing $11 \mathrm{~kg}$ and fitted with three duckfeet set at $0.5-\mathrm{m}$ width. Hand weeding in methods $\mathrm{W}_{\mathrm{a}+\mathrm{h}}$ and $\mathrm{W}_{\mathrm{f}}$ was done using a local long handled push hoe typical for the sandy soils in Niger (Raynaut, 1984). A local pearl millet cultivar, Sadore local (110 days) was compared with an improved early maturing cultivar, CIVT (90 days).

Treatments were replicated six times in $4 \times 2 \times 2$ factorial experiment with the weeding method by tillage by cultivar interaction confounded with blocks of eight plots each. Treatments were permanently assigned to plots. The plot size was $3 \times 20 \mathrm{~m}$.

A blanket application of $13.1 \mathrm{~kg} \mathrm{ha}^{-1}$ of $\mathrm{P}$ (single superphosphate containing boron in 1987, and single superphosphate in 1988 and 1989) was broadcast applied each season before sowing or tillage. In all plots nitrogen (calcium ammonium nitrate) was side dressed at a rate of $40 \mathrm{~kg} \mathrm{ha}^{-1}$ in a split application, 2 to 3 and 4 to 6 weeks after sowing. Pearl millet was sown at a depth of 3 to $4 \mathrm{~cm}$ in hills spaced $0.66 \mathrm{~m}$ using a tractor mounted four row unit planter. In hill-drop planting a cluster of seeds is released at set intervals. Row spacing was $0.75 \mathrm{~m}$. In ridged plots millet was sown on top of the ridge. Two to 3 weeks after sowing stands were thinned to obtain 10000 hills ha $^{-1}$ with three seedlings per hill. Crop residues were removed each year. Dates of field operations 
1987

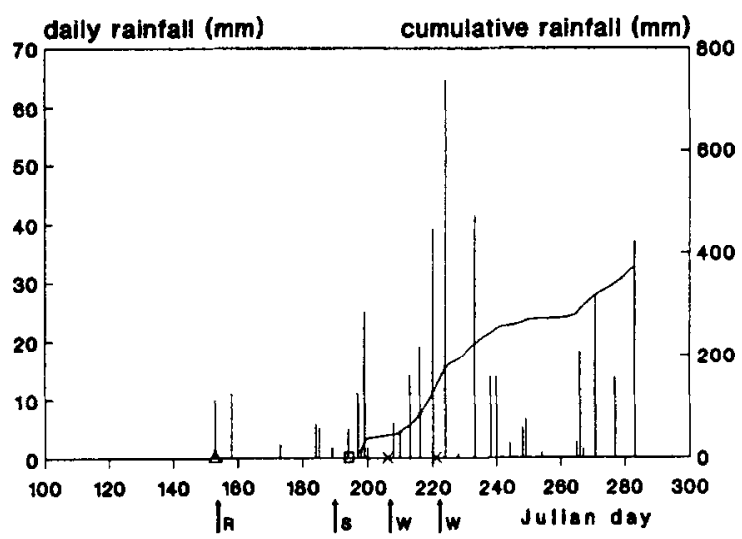

1988

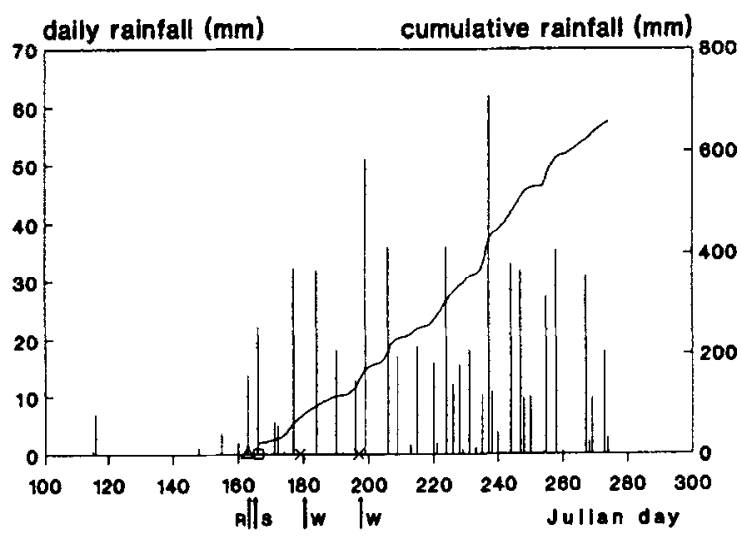

1989

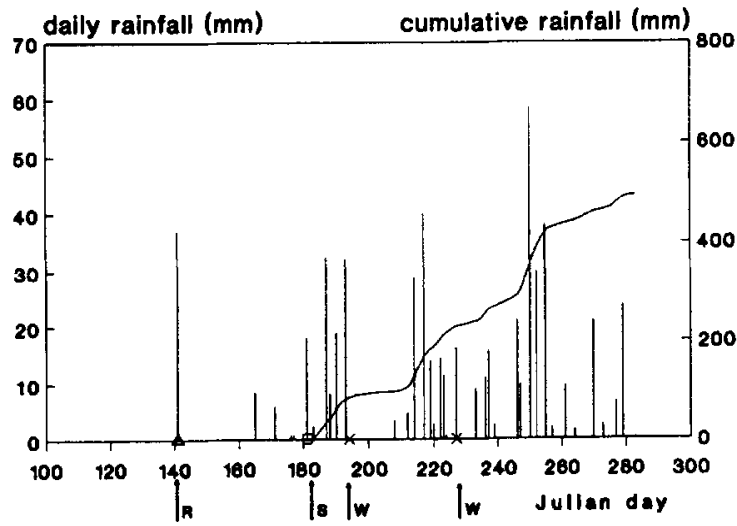

Fig. 1. Daily rainfall and cumulative rainfall for the 1987 to 1989 cropping seasons ( $R$, dates of pre-sowing tillage (ridging); $\mathrm{S}$, dates of sowing; $\mathrm{W}$, dates of weeding). 
depended on rainfall received (Fig. 1). Total rainfall received by the crop during the first 92 days after sowing was $361 \mathrm{~mm}$ in 1987, $581 \mathrm{~mm}$ in 1988, and $510 \mathrm{~mm}$ in 1989.

\subsection{Weed and crop sampling techniques}

In order to avoid border effects between weeds, and weeds and pearl millet, we divided each plot into two study areas, one half for weed sampling, the other for crop measurements.

Every year in each plot, weeds were sampled at four times during the crop cycle. Between-row and within-row weeds were separately cut at the soil surface, oven dried, and weighed. Experience with the donkey-powered weeder $\left(\mathrm{W}_{\mathrm{a}}\right)$ showed that a $0.25-\mathrm{m}$ wide strip centered in the crop row is left untouched. Therefore, weeds growing in this strip were considered within-row weeds and, having a 0.75 -m row distance, within-row weeds would grow in $1 / 3$, and between-row weeds in $2 / 3$ of the field. To represent this proportion we demarcated each sampling area using a $1.50 \times 1.33-\mathrm{m}$ rectangular frame with the long side placed perpendicular to the row direction and centered over two rows. This way $2 / 3 \mathrm{~m}^{2}$ of within-row weeds, and $4 / 3 \mathrm{~m}^{2}$ of between-row weeds were sampled. Weed dry matter was calculated on an area basis.

We determined millet seedling vigor from shoot dry weight. Millet stands after thinning and at harvest, and millet grain and stover yields were determined from $15 \mathrm{~m}^{2}$ of the two center crop rows.

Daily and cumulative rainfall following sowing during the crop cycles of 1987, 1988, and 1989 are presented in Fig. 1.

Labor requirements for the $\mathrm{W}_{\mathrm{f}}$ and $\mathrm{W}_{\mathrm{a}}$ weeding method were taken from a replicated large plot on-station field experiment in which millet was grown on a similar soil following the same agronomic practices.

Table 1

Abundantly present weeds in the experiment

\begin{tabular}{ll}
\hline Species & Family \\
\hline Alysicarpus ovalifolius (Schume. and Thonn.) J.Leonard & Fabaceae \\
Aristida sieberiana Trin. & Poaceae \\
Borreria radiata D.C. & Rubiaceae \\
Chamaecrista mimosoides (L.) Greene & Caesalpiniaceae \\
Fimbristylis sp. & Cyperaceae \\
Indigofera pilosa Poir. & Fabaceae \\
Indigofera Strobilifera (Hochst) Hochst ex Bak. & Fabaceae \\
Lpomoea vagans Bak. & Convolvulaceae \\
Limeum viscosum (Gay.) Fenz. & Molluginaceae \\
Merremia pinnata (Hochst ex Choisy) Hallier f. & Convolvulaceae \\
Mitracarpus scaber Zucc. & Rubiaceac \\
Polycarpaealinearifolia (D.C.) D.C. & Caryophyllaceae \\
Sida cordifolia L. & Malvaceae \\
Spermacoce stachydea D.C. & Rubiaceae \\
Tephrosia linearis (Willd.) Pers. & Fabaceae \\
Tephrosia purpurea (L.) Pers. & Fabaceae \\
Waltheria indica L. & Sterculiaceae \\
\hline
\end{tabular}




\subsection{Predominant weed species}

The objective of the reported experiment does not include a detailed investigation into the effects of weed management on numbers, weight or shift of weed species. However, the predominant weed species were determined (G. Schmelzer, personal communication, 1989) (Table 1), and we approximately evaluated their seasonal occurrence in terms of area covered.

\subsection{Statistical analysis}

Data were analyzed by individual years and combined over years by analysis of variance using GENSTAT 5 release 3.

\section{Results and discussion}

\subsection{Weed growth}

Because of the significant effects of: year $(P \leq 0.001)$, year by weeding method $(P \leq 0.001)$, and year by pre-sowing tillage interactions $(P \leq 0.05)$ for most sampling times, seasonal weed dry matter data are presented for individual years in Tables 2-4.

Table 2

Weeding, tillage, and cultivar effect on within-row and between-row weed dry matter $\left(\mathrm{kg} \mathrm{ha}^{-1}\right)$ during the crop cycle of 1987. Weeding dates 12 and 27 days after sowing

\begin{tabular}{|c|c|c|c|c|c|c|c|c|}
\hline \multirow[t]{3}{*}{ Treatment } & \multicolumn{8}{|c|}{ Sampling time (days after sowing) } \\
\hline & \multicolumn{4}{|c|}{ Between-row } & \multicolumn{4}{|c|}{ Within-row } \\
\hline & 19 & 31 & 72 & 93 & 19 & 31 & 72 & 93 \\
\hline \multicolumn{9}{|c|}{$\overline{\text { Weeding method }}{ }^{2}$} \\
\hline$w_{0}$ & 118 & 868 & 2635 & 2957 & 121 & 929 & 3332 & 3815 \\
\hline $\mathrm{w}_{\mathrm{a}}$ & 20 & 65 & 797 & 1419 & 107 & 898 & 5241 & 5065 \\
\hline$W_{a+n}^{a}$ & 11 & 13 & 326 & 551 & 48 & 27 & 548 & 1011 \\
\hline $\mathrm{W}_{\mathrm{f}}$ & 5 & 8 & 76 & 206 & 57 & 19 & 191 & 395 \\
\hline$S E^{b}$ & 7.7 & 33.6 & 91.9 & 126.0 & 7.0 & 57.5 & 199.2 & 212.6 \\
\hline \multicolumn{9}{|l|}{ Tillage } \\
\hline No-till & 47 & 270 & 1037 & 1306 & 78 & 453 & 2225 & 2342 \\
\hline Ridging & 30 & 206 & 880 & 1260 & 88 & 483 & 2431 & 2802 \\
\hline \multicolumn{9}{|l|}{ Cultivar } \\
\hline Sadore 1. & 37 & 214 & 957 & 1129 & 84 & 526 & 2503 & 2619 \\
\hline CIVT & 40 & 263 & 960 & 1437 & 82 & 413 & 2153 & 2525 \\
\hline $\mathrm{SE}^{\mathrm{r}}$ & 5.5 & 23.7 & 65.0 & 89.1 & 5.0 & 40.6 & 140.9 & 150.3 \\
\hline
\end{tabular}

\footnotetext{
${ }^{a} W_{0}$, no weeding; $W_{a}$, between-row weeding by animal traction; $W_{a+n}$, between-row weeding by animal traction plus additional within-row hand weeding; $W_{f}$, full field hand weeding.

${ }^{b} \mathrm{SE}$, standard error of means for weeding method.

${ }^{c} \mathrm{SE}$, standard error of means for tillage or cultivar.
} 
Table 3

Weeding, tillage, and cultivar effect on within-row and between-row weed dry matter $\left(\mathrm{kg} \mathrm{ha}^{-1}\right)$ during the crop cycle of 1988 . Weeding dates 13 and 31 days after sowing

\begin{tabular}{|c|c|c|c|c|c|c|c|c|}
\hline \multirow[t]{3}{*}{ Treatment } & \multicolumn{8}{|c|}{ Sampling time (days after sowing) } \\
\hline & \multicolumn{4}{|c|}{ Between-row } & \multicolumn{4}{|c|}{ Within-row } \\
\hline & 29 & 48 & 70 & 94 & 29 & 48 & 70 & 94 \\
\hline \multicolumn{9}{|c|}{ Weeding method ${ }^{\text {a }}$} \\
\hline $\mathrm{W}_{0}$ & 1282 & 2834 & 3082 & 2918 & 1143 & 2948 & 3715 & 3169 \\
\hline $\mathrm{W}_{\mathrm{a}}$ & 429 & 957 & 1680 & 1571 & 1433 & 3425 & 4338 & 4512 \\
\hline$w_{a+h}$ & 158 & 132 & 156 & 377 & 258 & 138 & 294 & 505 \\
\hline$W_{f}$ & 47 & 15 & 92 & 146 & 109 & 34 & 93 & 129 \\
\hline$S^{b}$ & 40.9 & 94.3 & 121.5 & 124.7 & 75.4 & 139.4 & 159.4 & 220.6 \\
\hline \multicolumn{9}{|l|}{ Tillage } \\
\hline No-till & 624 & 1100 & 1352 & 1316 & 947 & 1888 & 2513 & 2504 \\
\hline Ridging & 333 & 869 & 1152 & 1190 & 525 & 1385 & 1707 & 1653 \\
\hline \multicolumn{9}{|l|}{ Cultivar } \\
\hline Sadore 1. & 484 & 966 & 1266 & 1266 & 740 & 1713 & 2018 & 1902 \\
\hline CIVT & 474 & 1033 & 1238 & 1240 & 732 & 1560 & 2203 & 2255 \\
\hline $\mathrm{SE}^{\mathrm{c}}$ & 28.9 & 66.7 & 85.9 & 88.2 & 53.2 & 98.6 & 112.7 & 156.0 \\
\hline
\end{tabular}

${ }^{a} W_{0}$, no weeding; $W_{a}$, between-row weeding by animal traction; $W_{a+n}$, between-row weeding by animal traction plus additional within-row hand weeding; $W_{f}$, full field hand weeding.

${ }^{b} \mathrm{SE}$, standard error of means for weeding method.

${ }^{c}$ SE. standard error of means for tillage or cultivar.

\subsubsection{Weeding method effects}

Weeding method was the single most important factor significantly affecting dry matter of weeds between-row and within-row in all years at all sampling times. Compared with the weedy check, weed dry matter decreased as the amount of weed control increased from $W_{a}$ to $W_{a+h}$, to $W_{f}$. The $W_{a}$ method, potentially only controlling between-row weeds, was significantly less effective in doing so than the other methods. Furthermore, compared with the weedy check, within-row weed dry matter of the $\mathrm{W}_{\mathrm{a}}$ method was significantly greater in 1987 and 1988 on the last two sampling times. We observed that the removal of competing between-row weeds had benefited the remaining within-row weeds whose canopies eventually touched between the millet rows. Additional hand weeding within the row as included in the $\mathrm{W}_{\mathrm{a}+\mathrm{h}}$ method decreased weed dry matter considerably, particularly at the first two sampling times, when weed crop competition effects are critical. The $\mathrm{W}_{\mathrm{f}}$ method did not significantly decrease weed dry matters over the $W_{a+h}$ method.

An important factor contributing to successful weed control relates to the difference in quality between hand and mechanical weeding. Betker (1991) found at the ICRISAT Sahelian Center, that one hand weeding killed $93 \%$, while a single pass with the donkey-drawn weeder killed only $30 \%$ of the weeds in a millet crop having a dry matter weed infestation of $75 \mathrm{~kg} \mathrm{ha}^{-1}$. These data compare well with the between-row weediness levels of the $\mathrm{W}_{\mathrm{a}}$ and $\mathrm{W}_{\mathrm{a}+\mathrm{h}}$ weeding treatments. Obviously, conscientious hand weeding delivers the highest quality in weed control (Terry, 1981). 
Table 4

Weeding, tillage, and cultivar effect on within-row and hetween-row weed dry matter $\left(\mathrm{kg} \mathrm{ha}^{-1}\right)$ during the crop cycle of 1989 . Weeding dates 13 and 46 days after sowing

\begin{tabular}{|c|c|c|c|c|c|c|c|c|}
\hline \multirow[t]{3}{*}{ Treatment } & \multicolumn{8}{|c|}{ Sampling time (days after sowing) } \\
\hline & \multicolumn{4}{|c|}{ Between-row } & \multicolumn{4}{|c|}{ Within-row } \\
\hline & 29 & 47 & 69 & 93 & 29 & 47 & 69 & 93 \\
\hline \multicolumn{9}{|c|}{ Weeding method ${ }^{\text {a }}$} \\
\hline$w_{0}$ & 1174 & 2379 & 3152 & 3674 & 1138 & 2185 & 2654 & 3225 \\
\hline $\mathrm{w}_{\mathrm{a}}$ & 605 & 1256 & 1046 & 1537 & 554 & 1799 & 2428 & 3257 \\
\hline$W_{3+h}$ & 120 & 531 & 636 & 1106 & 76 & 270 & 154 & 1034 \\
\hline$w_{f}$ & 17 & 134 & 62 & 248 & 47 & 158 & 82 & 460 \\
\hline$S E^{\circ}$ & 52.7 & 105.6 & 133.7 & 179.1 & 69.6 & 163.2 & 150.6 & 248.3 \\
\hline \multicolumn{9}{|l|}{ Tillage } \\
\hline No-till & 728 & 1255 & 1290 & 1612 & 682 & 1350 & 1558 & 2294 \\
\hline Ridging & 230 & 894 & 1158 & 1670 & 225 & 856 & 1101 & 1694 \\
\hline \multicolumn{9}{|l|}{ Cultivar } \\
\hline Sadore 1. & 521 & 1020 & 1279 & 1651 & 425 & 1063 & 1352 & 2010 \\
\hline CIVT & 438 & 1133 & 1169 & 1631 & 482 & 1143 & 1307 & 1978 \\
\hline$S E^{c}$ & 37.2 & 74.7 & 94.5 & 126.6 & 49.2 & 115.4 & 106.5 & 175.6 \\
\hline
\end{tabular}

${ }^{a} W_{0}$, no weeding; $W_{a}$, between-row weeding by animal traction; $W_{a+h}$. between-row weeding by animal traction plus additional within-row hand weeding; $W_{f}$, full field hand weeding.

${ }^{b} \mathrm{SE}$, standard error of means for weeding method.

${ }^{c} \mathrm{SE}$, standard error of means for tillage or cultivar.

\subsubsection{Tillage effects}

Compared with no-till, pre-sowing ridging significantly reduced the amount of within-row weeds throughout the seasons of 1988 and 1989 by 33 to $74 \%$. In 1987, there was no difference in the amount of within-row weeds, except at harvest when ridging resulted in $20 \%$ more weeds. In all years, an important reduction of 32 to $79 \%$ in between-row weed dry matter was noted during the first two sampling times (not significant at 31 days after sowing (DAS) in 1987). This is a crucial timely reduction since the critical competition period is during the early life of the crop. For instance, sorghum and millet in India produced the highest yield when the crops were kept weed free for the first 6-7 weeks (ICRISAT, 1976).

We found a significant tillage by weeding method interaction effect on average weed dry matter both in 1988 and 1989 at 29 DAS, after one weeding. In this early stage of crop growth ridging enhanced weed control by the $\mathrm{W}_{\mathrm{a}}$ weeding method, which had a significantly reduced (by 20 to $30 \%$ ) weed dry matter compared with plots without primary tillage (Table 5).

The effectiveness of pre-sowing ridging in reducing weeds seems to be related to the occurrence of storms before and after tillage, and the delay in sowing after tillage. For instance, in 1987 there was no rain before the one storm that allowed tillage, but four storms of $>5 \mathrm{~mm}$ occurred after tillage in the period of 42 days until sowing (Fig. 1). Consequently, weeds had emerged before sowing rendering weed competition almost as intense as under no-till conditions. In contrast, in 1988 two small storms provoked 
Table 5

Interaction of pre-sowing tillage and weeding on average weed dry weight $\left(\mathrm{kg} \mathrm{ha}^{-1}\right)$ at 29 days after sowing

\begin{tabular}{|c|c|c|c|c|c|c|}
\hline \multirow[t]{3}{*}{ Treatment } & \multicolumn{6}{|l|}{ Season } \\
\hline & \multicolumn{2}{|l|}{1987} & \multicolumn{2}{|l|}{1988} & \multicolumn{2}{|l|}{1989} \\
\hline & No-till & Ridge & No-till & Ridge & No-till & Ridge \\
\hline \multicolumn{7}{|c|}{ Weeding method } \\
\hline $\mathrm{w}_{0}$ & 968 & 768 & 1510 & 1053 & 1737 & 538 \\
\hline $\mathrm{W}_{\mathrm{a}}$ & 89 & 41 & 658 & 199 & 858 & 249 \\
\hline$W_{a+h}$ & 16 & 9 & 258 & 58 & 97 & 55 \\
\hline$W_{\mathrm{f}}$ & 8 & 8 & 71 & 23 & 35 & 58 \\
\hline$S E^{b}$ & \multicolumn{2}{|c|}{47.5} & \multicolumn{2}{|c|}{57.9} & \multicolumn{2}{|c|}{98.5} \\
\hline
\end{tabular}

${ }^{a} W_{0}$, no weeding; $W_{a}$, between-row weeding by animal traction; $W_{a+h}$, between-row weeding by animal traction plus additional within-row hand weeding; $W_{f}$, full field hand weeding.

${ }^{b} \mathrm{SE}$, standard error of means of treatment interaction.

germination of weeds, which were subsequently covered by ridging. As ridging was followed immediately by sowing, there was an early advantage to the crop. In 1989, the pattern appears to be similar to that of 1987 , except that in the 2-week dry period following tillage, emerged weeds died.

Because millet yields would be affected by both within-row and between-row weeds, we also analyzed treatment effects for the total weed dry weight (data not shown). We found similar tillage by weeding method interactions as for the within-row and betweenrow weeds analysis. There was no evidence that growing millet for 3 consecutive years, increased the amount of weeds, with the weedy check producing on average $3260 \mathrm{~kg}$ $\mathrm{ha}^{-1}$ of weed dry matter each year. Ilowever, the weed composition, determined in 1988 and 1989, changed depending on weeding method and tillage. In 1988 we found leguminous weeds occupying an increasing soil surface area during the season in non-weeded plots. Increasing the amount of weeding created a shift to broadleaved weeds and an associated reduction of the area covered by grassy weeds. Trends were similar during the 1989 season, but the leguminous weeds disappeared. Ridging had a similar effect on weed composition as weeding with untilled plots having about twice as many grasses as did ridged plots.

\subsubsection{Cultivar effect}

No significant differences were found between the cultivars used in their capability to smother weeds, except for between-row weeds at harvest in 1987, when we found 1129 $\mathrm{kg} \mathrm{ha}^{-1}$ of weed dry matter for the local compared with $1437 \mathrm{~kg} \mathrm{ha}^{-1}$ for CIVT. This could be expected as early in the season growth differences between the two cultivars are small, with the local variety eventually producing more biomass than the shorter duration CIVT.

\subsection{Millet yield}

Total rainfall received during the cultivation of the crop, and its distribution resulted in water not being an important limiting factor on crop yield. For instance during the 
Table 6

Effect of pre-sowing ridging on pearl millet establishment (shoot dry weight in g per hill)

\begin{tabular}{llll}
\hline Treatment & \multicolumn{3}{l}{ Season and days after sowing (DAS) } \\
\cline { 2 - 4 } & 1987 14 DAS & 1988 10 DAS & 198930 DAS \\
\hline Tillage & 1.9 & 1.1 & 4.9 \\
No-till & 2.6 & 4.6 & 9.3 \\
Ridging & 0.10 & 0.08 & 0.50 \\
SE $^{2}$ & & & \\
\hline
\end{tabular}

${ }^{a} \mathrm{SE}$, standard error of means.

1987 season, in which the crop received $361 \mathrm{~mm}$, yields were about the same as in the 1988 season during which $582 \mathrm{~mm}$ was received. However, the 14-day dry period early in the season of 1989 (Fig. 1), and a severe infestation by a head worm Raghuva (Heiliocheilus (Raghuva) albipunctella) might have contributed to the substantially reduced yields for that year.

In all years millet seedling vigor was significantly greater in ridged plots than in plots without primary tillage; however, in 1987 the effect was minimal (Table 6). Millet seedling vigor is consistent with its early advantage over weeds in 1988 and 1989 , depending on the weather which dictated the timing of ridging and sowing, as discussed earlier. During the experiment there were no significant treatment effects on crop stands up to harvest. Hence, the treatments did not affect crop yields by their effect on stands. The exception occurred in 1989, when at harvest stands in the $\mathrm{W}_{0}$ plots had been reduced to about $80 \%$ of the average stands (data not shown).

In all years, pre-sowing ridging significantly increased both grain yield by 58 to $71 \%$, and stover yield by 56 to $82 \%$ over the no-till treatment, with the exception of grain yield in 1987 (Table 7). There was an important interaction between the effects of tillage and weeding method on millet yields. The trend was similar for both grain and stover yields (data not shown) and indicated that pre-sowing ridging becomes increasingly important in controlling weeds, and hence in influencing crop yields, as the amount of weed control in the crop becomes lower (Table 8).

During the experiment the sum of weed dry matter and crop dry matter was virtually constant for all weeding methods (Tables 2-4 and 7). Thus treatment effects reflected a shift in the competition between the crop and the weeds. The amount of weed control was the most important factor in controlling seasonal weed levels, and it consistently and significantly influenced millet yields. The highest average millet grain yields were obtained with the $\mathrm{W}_{\mathrm{f}}$ method. Almost as effective was the $\mathrm{W}_{\mathrm{a}+\mathrm{h}}$ method, producing millet grain yields of 78 to $100 \%$ of the $\mathrm{W}_{\mathrm{f}}$ method, depending on the year. Lastly, the $W_{a}$ method resulted in considerably lower crop yields which were between 28 to $34 \%$ of those with the $W_{f}$ method. Such a yield loss cannot be compensated for by the modest reduction in labor rates associated with this weeding method.

\subsection{Weeding labor requirements}

The $\mathrm{W}_{\mathrm{a}}$ weeding method required $21.2 \mathrm{~h} \mathrm{ha}^{-1}$ while the $\mathrm{W}_{\mathrm{f}}$ weeding method required the highest labor rate of $70.1 \mathrm{~h} \mathrm{ha}^{-1}$. Method $\mathrm{W}_{\mathrm{a}+\mathrm{h}}$, combining mechanized weeding 
Table 7

Effect of weeding, tillage, and variety on millet grain and stover yield $\left(\mathrm{kg} \mathrm{ha}^{-1}\right)$

\begin{tabular}{|c|c|c|c|c|c|c|}
\hline \multirow[t]{2}{*}{ Treatment $^{a}$} & \multicolumn{3}{|c|}{ Grain yield } & \multicolumn{3}{|c|}{ Stover yield } \\
\hline & 1987 & 1988 & 1989 & 1987 & 1988 & 1989 \\
\hline \multicolumn{7}{|c|}{ Weeding method ${ }^{b}$} \\
\hline $\mathrm{w}_{0}$ & 100 & 50 & 6 & 307 & 354 & 23 \\
\hline $\mathrm{w}_{\mathrm{a}}$ & 326 & 287 & 87 & 844 & 1055 & 330 \\
\hline$W_{a+h}$ & 835 & 1012 & 218 & 1777 & 3167 & 719 \\
\hline$w_{f}$ & 952 & 1012 & 279 & 2174 & 3192 & 1055 \\
\hline$S E^{c}$ & 51.6 & 58.7 & 23.9 & 102.6 & 171.5 & 97.2 \\
\hline \multicolumn{7}{|l|}{ Tillage } \\
\hline No-till & 663 & 640 & 143 & 1445 & 2114 & 503 \\
\hline Ridging & 745 & 901 & 246 & 1752 & 2829 & 900 \\
\hline$S E^{d}$ & 42.1 & 47.9 & 19.5 & 83.7 & 140.1 & 79.3 \\
\hline \multicolumn{7}{|l|}{ Cultivar } \\
\hline Sadore local & 819 & 863 & 230 & 1942 & 2900 & 885 \\
\hline CIVT & 589 & 678 & 160 & 1256 & 2043 & 517 \\
\hline$S E^{e}$ & 42.1 & 47.9 & 19.5 & 83.7 & 140.1 & 79.3 \\
\hline
\end{tabular}

${ }^{a} W_{0}$ values were excluded from the analyses of variance for the calculation of standard errors of means. Means of tillage and cultivar levels are calculated excluding $W_{0}$ levels.

${ }^{b} W_{0}$, no weeding; $W_{a}$, between-row weeding by animal traction; $W_{a+h}$, between-row weeding by animal traction plus additional within-row hand weeding; $W_{f}$, full field hand weeding.

${ }^{c} \mathrm{SE}$, standard error of means for weeding method.

¿ $\mathrm{SE}$, standard error of means for tillage.

e SE, standard error of means for cultivar.

with within-row hand weeding required $51.8 \mathrm{~h} \mathrm{ha}^{-1}$ (Table 9). These weeding labor rates are much lower than reported elsewhere in the Sahelian zone, probably because of the unique use of the long handled hoe appropriate for millet cultivation in sandy soils. Because farmers normally weed within-row weeds while thinning the millet, adoption of the $\mathrm{W}_{\mathrm{a}+\mathrm{h}}$ method would seem uncomplicated. The use of donkeys for between-row

Table 8

Effect of pre-sowing tillage and weeding method on millet grain yield $\left(\mathrm{kg} \mathrm{ha}^{-1}\right)$. Average of three seasons

\begin{tabular}{lcc}
\hline Treatment & No-till & Ridge \\
\hline${\text { Weeding } \text { method }^{\mathrm{a}}}_{\mathrm{W}_{\mathrm{o}}}$ & 31 & 73 \\
$\mathrm{~W}_{\mathrm{a}}$ & 128 & 339 \\
$\mathrm{~W}_{\mathrm{a}+\mathrm{h}}$ & 602 & 775 \\
$\mathrm{~W}_{\mathrm{f}}$ & 717 & 778 \\
SE $^{\mathrm{b}}$ & & \\
\hline
\end{tabular}

\footnotetext{
${ }^{a} \mathrm{w}_{0}$, no weeding; $\mathrm{w}_{\mathrm{a}}$, between-row weeding by animal traction; $\mathrm{w}_{\mathrm{a}+\mathrm{h}}$, between-row weeding by animal traction plus additional within-row hand weeding; $W_{f}$, full field hand weeding.

${ }^{b} \mathrm{SE}$, standard error of means of treatments interaction.
} 
Table 9

Seasonal weeding requirements $\left(\mathrm{h} \mathrm{ha}^{-1}\right)$, average from 2 years, standard error in parentheses

\begin{tabular}{llll}
\hline Weeding method & First weeding & Second weeding & Total \\
\hline Between-row cultivator & $10.4(1.01)$ & $10.8(2.02)$ & $21.2(2.30)$ \\
Within-row hand weeding & $15.8(2.83)$ & $14.8(1.73)$ & $30.6(3.27)$ \\
Full field hand weeding & $39.0(4.22)$ & $31.1(2.45)$ & $70.1(5.28)$ \\
\hline
\end{tabular}

cultivation reduced total weeding time by a modest $18.3 \mathrm{~h} \mathrm{ha}^{-1}$, but it could be important because the saving in labor time is accrued during the critical period for crop weed competition.

\section{Conclusion}

The amount of weeding in the crop was the single most important factor in controlling weed growth and, hence, in influencing crop yields.

In the mechanized between-row only method of weeding, within-row weed growth exceeded that of the weedy check, which resulted in unacceptable crop yield losses. However, pre-sowing ridging reduced the growth of within-row weeds in this case. Full field hand weeding, or the combination of between-row animal traction weeding and supplemental within-row weeding achieved similar, and adequate amounts of weed control. Hence, mechanized weeding with supplemental within-row weeding is recommended as the best combination for weed control in terms of crop yield.

Pre-sowing ridging reduced seasonal weed growth and produced higher pearl millet yields than cultivation without primary tillage. Seasonal weed growth did not increase during the three seasons of continuous millet cultivation.

\section{References}

Betker, J., 1991. Untersuchung leistungsspezifischer Kenngroessen der Zugtiemutzung im suedlichen Niger. Dissertation, Universitaet Hohenheim, Stuttgart, Germany.

Carson, A.G., 1987. Improving weed management in the draft animal-based production of pearl millet in the Gambia. Trop. Pest Manage., 33: 359-363.

Choudhary, A.H. and Lagoke, S.T.O., 1981. Weeding control in pearl millet in the savanna zone of Nigeria. Trop. Pest Manage., 27: 465-471.

FAO/UNESCO, 1977. Soil Map of the World 1: 5000000. Vol. VI. Africa. UNESCO, Paris.

Hoogmoed, W.B. and Klaij, M.C., 1990. Soil management for crop production in the Sahel. I: Soil and climate parameters. Soil Tillage Res., 16: 85-103.

International Crops Research Institute for the Semi-Arid Tropics (ICRISAT), 1976. Annual Report 1975-76. ICRISAT, Patancheru, India.

Intemational Crops Research Institute for the Semi-Arid Tropics (ICRISAT), 1988. ICRISAT West African Programs Annual Report 1987. ICRISAT Sahelian Center, Niamey, Niger.

International Crops Research Institute for the Semi-Arid Tropics (ICRISAT), 1991. ICRISAT West African Programs Annual Report 1990. ICRISAT Sahelian Center, Niamey, Niger.

Intemational Crops Research Institute for the Semi-Arid Tropics (ICRISAT), 1992. ICRISAT Report 1991. In:

En. Summaries in En, Fr. Es. ICRISAT, Patancheru, India, 116 pp. 
Klaij, M.C., 1983. Analysis and evaluation of tillage on an Alfisol in a semi-arid tropical region of India. Ph.D. Thesis, Agricultural University of Wageningen, The Netherlands, $148 \mathrm{pp}$.

Klaij, M.C., Renard, C. and Reddy, K.C., 1994. Low-input technology options for millet-based cropping systems in the Sahel. Exp. Agric., 30: 77-82.

Kuipers, H., 1975. The objectives of soil tillage. In: Report on Expert Consultation Meeting on the Mechanization of Rice Production, jointly sponsored by IITA, FAO, and the Government of the Netherlands, 10-14 June 1974. IITA, Ibadan, Nigeria, pp. 61-65.

Norman, D.W., Newman, M.D. and Ouedraogo, 1., 1981. Farm and village production systems in the semi-arid tropics of West Africa: An interpretive review of research. ICRISAT Research Bulletin No. 4, Vol. 1, International Crops Research Institute for the Semi-Arid Tropics (ICRISAT), Patancheru, Andhra Pradesh, India, 94 pp.

Raynaut, C., 1984. Outils agricoles de la region de Maradi (Niger). Cah. ORSTOM, Ser. Sci. Hum., XX(3-4): $505-536$.

Terry, P.J., 1981. Weeds and their control in the Gambia. Trop. Pest Manage., 27: 44-52.

West, L.T., Wilding, L.P., Landeck, J.K. and Calhoun, F.G., 1984. Soil survey of the ICRISAT Sahelian Center. Soil Crops Science Dept./Tropsoils, Texas A\&M, College Station, Texas. 